Jpn. J. Med. Mycol.

Vol. 31, 355-361, 1990

ISSN $0916-4804$

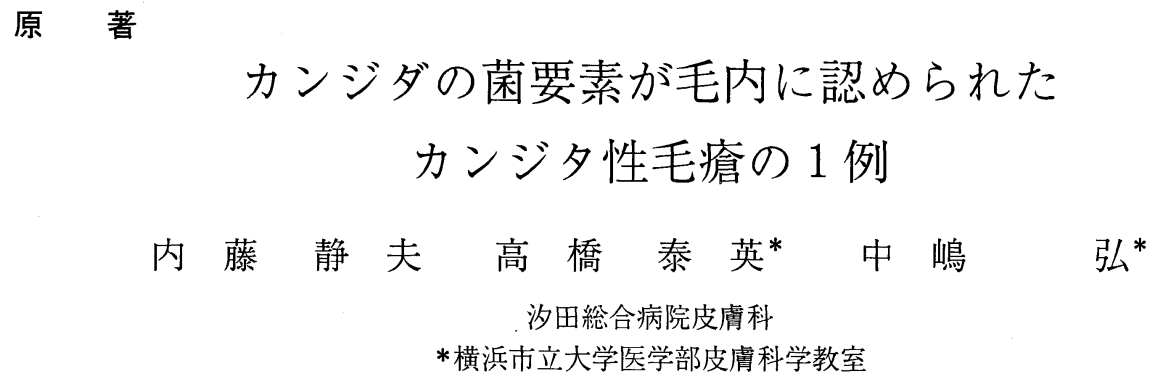

〔受付 3 月 15 日, 1990 年. 受理 5 月 18 日, 1990年]

\begin{abstract}
要旨
43 歳男の覚醒剤中毒患者にみられたカンジダ性毛瘡の 1 例を報告した。胃穿孔術後で各種抗生剂使 用後に, 主として須毛部に一致して膿疮が出現した。抜去した毛の $\mathrm{KOH}$ 標本および PAS 染色標本で 毛内外に菌要素を認めた. 病理組織学的には, 破壊された毛包を中心に稠密な細胞浸潤があり, その中 央部には膿瘍が認められた.PAS 染色では, 組織中の内毛根鞘および毛内に胞子および仮性菌系と思 われる菌要素が認められた.モノクローナルおよびポリクローナル抗カンジダ抗体によるPAP 法では, 毛内外の菌要素は陽性であった。真菌培養では, 毛から Candida albicans type A が分離同定された. 治療では, クロトリマゾール外用は無効，グリセオフルビン内服で増悪，イトラコナゾール内服で著明 に改善された。
\end{abstract}

Key words： カンジダ性毛瘡 (Folliculitis barbae Candidomycetica), Candida albicans, 抗カンジタ抗体 (anti-Candida albicans antibody), 毛内カンジダ増殖 (endothrix Candida-growth), PAP method, Candida albicans producing proteinase (CAPP), 覚醒剤中毒 (methamphetamine addiction)

カンジダ性毛瘡は必ずしも稀な疾患でないが, カンジダの菌要素が毛内に認められたとする報告 は少ない1 3). しかも, これらの症例では, 毛内 の菌要素がカンジダであることは証明されていな (2,3). 今回我々は, 覚醒剂中毒患者に生じたカ ンジダ性毛瘡の 1 例で, 毛内の菌要素が免疫組織 化学的にカンジダであることが証明されたので, 報告する。

症 例: 43 歳, 男.

初診: 1988 年 8 月 8 日.

家族歴：特記すべきことなし.

既往歴 : 10年前から覚醒剂（メタンフェタミン） 中毒である。

別刷請求先 : 内藤 静夫

干 232 横浜市南区浦舟町 3-46 横浜市立大学医学部皮膚科学教室
現病歴 : 1988 年 6 月 30 日, 急性腹症のため汐 田総合病院内科に入院した。胃潰瘍穿孔のため 7 月 8 日同外科に転科し，7月 11 日胃部分切除術を 受け，8月 3 日まで高カロリー経静脈栄養を受け ていた。また, 術後, セファゾリン，トブラマイ シン, ラタモキセフ, クリンダマイシンなどの点 滴静注を 8 月 24 日まで連日受けていた。この間の 8 月 4 日から須毛部，一部頭髪部に，瘦痒のある 丘疹・膿疮が出現し, 8 月 8 日皮膚科に併診となっ た。

現 症: 初診時, 主に須毛部,一部頭髪部に, 毛包一致性・米粒大の膿疮が多発性にみられた。 同部から採取した毛の直接鏡検により真菌性菌要 素が認められたため, クロトリマゾールクリーム を約 2 週間塗布したが，皮疹は改善しなかった (Fig. 1). 


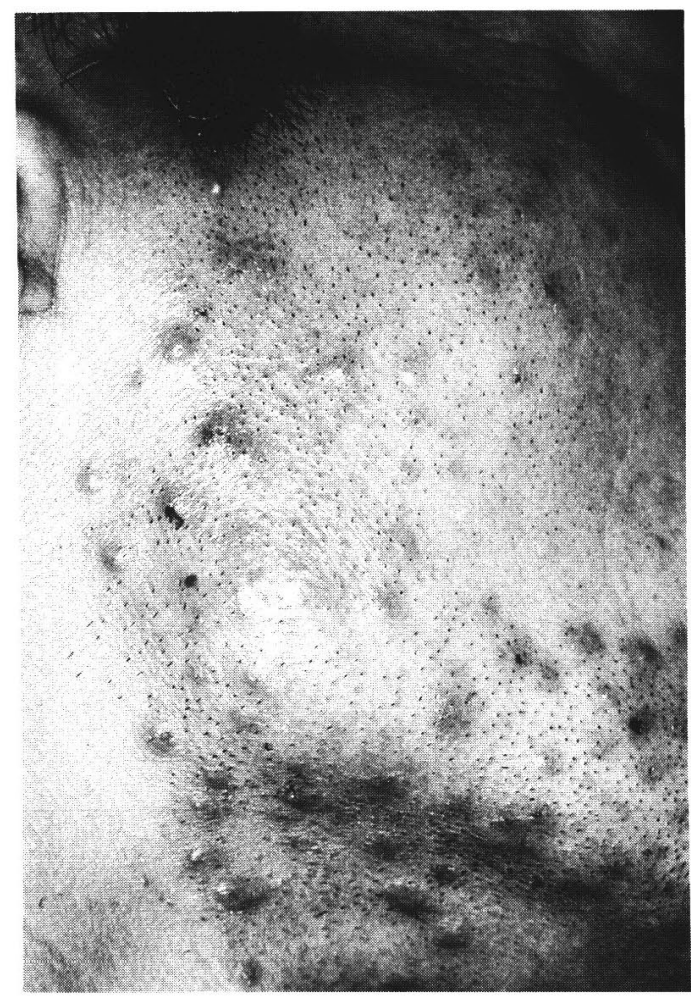

Fig. 1. Pustules and red papules on beards and whiskers after clotrimazole application.

検査成績：一般検査では，末梢血の白血球増加 $\left(10,700 / \mathrm{mm}^{3}\right)$, 血小板増加 $\left(59.6 \times 10^{4} / \mathrm{mm}^{3}\right)$, 血沈穴進 $(45 \mathrm{~mm} / \mathrm{hr}), \mathrm{CRP}(+), \mathrm{A} \cdot \mathrm{G}$ 比低下 （0.8）などの異常が認められた。免疫検查では, ッ反強陽性 $(9 \times 7 / 57 \times 42 \mathrm{~mm})$ ，末梢血 B 細胞の 低下（7％）が認められたが，免疫グロブリン， OKT $4 \cdot 8$ 比などは正常範囲内で, 抗 HIV 抗体も 陰性であった．7月 22 日の中心静脈カテーテル先 端からの一般細菌培養にてカンジダ属が検出され た。また，8月 8 日の須毛部の膿の一般細菌培養 でも，カンジダ属と表皮ブドウ球菌が検出された。

真菌学的検查 : 抜去した毛のサブローブドウ糖 寒天培地による真菌培養では，接種毛を中心にし て発育の早い乳白色クリーム状の菌集落が生じた. 集落の中心に脳回転状㱀壁が認められ，辺縁には 樹枝状の菌糸束が見られた（Fig．2）。糖利用試験 では, Glucose, Galactose, Sucrose, Maltose, Trehalose, Sorbose が同化され, Lactose, Raffi-

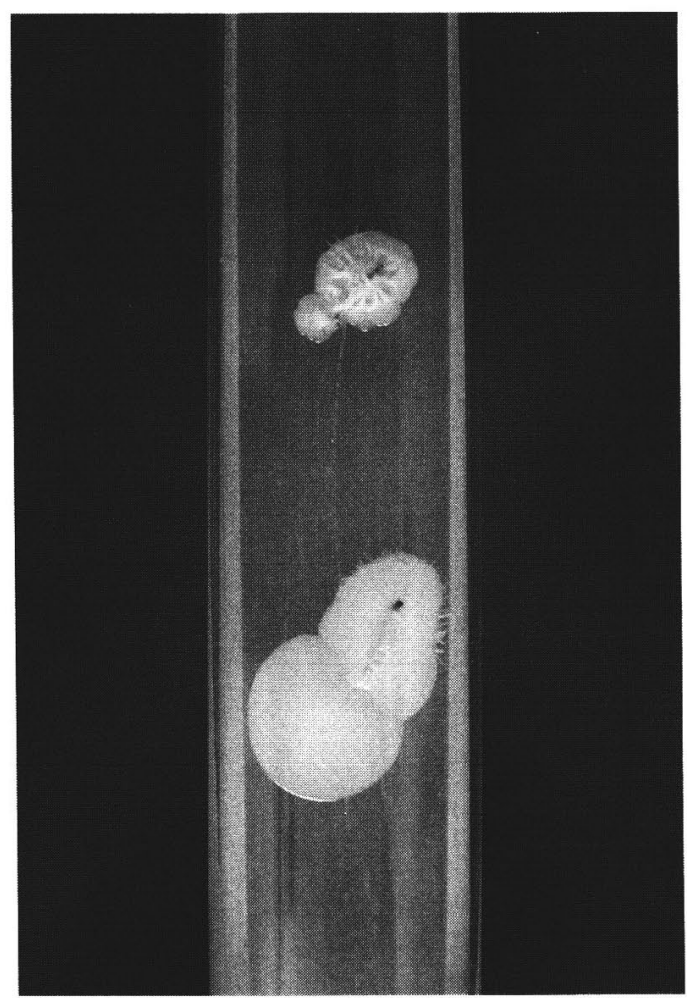

Fig. 2. White colonies on Sabouraud dextrose agar.

nose, Cellobiose, Inocitol, Ribitol, Dulcitol は 同化されなかった.また，コーンミール寒天培地 では厚膜胞子形成が認められ，Candida check で 本菌はCandida albicans type A と同定された。 なお, 真菌培養は計 3 回行われたが, 毎回同一菌 が分離され，白䍩菌は一度も分離されなかった。

病理組織学的所見：9月 3 日, 右顎下部の毛包 性膿疮を生検した。その HE 染色では，毛包を中 心として好中球と組織球による稠密な細胞浸潤が あり，その中央部は膿瘍を形成し，毛包壁は破壊 されていた（Fig. 3)。そのPAS 染色では，内毛 根鞘と毛皮質に辺縁が丸い仮性菌系様菌要素が認 められた (Fig. 4).

免疫組織化学的所見: 病理組織と同じ標本を抗 カンジダ・モノクローナル抗体 (DAKO 社, 1,000 ×希棌）および抗カンジダ・ポリクローナル抗体 (北里大学病理学教室製，1,000×希釈）を用いた 酵素抗体法（PAP 法）で染色したところ, 内毛根 
Table 1. Results of PAP stain by anti-Candida rabbit antiserum (by $\mathrm{H}$. Kume)

\begin{tabular}{lccc}
\hline antiserum dilution rate & $\times 100$ & $\times 500$ & $\times 1000$ \\
\hline Candida & + & + & + \\
Trichophyton & + & - & - \\
Microsporum & - & - & - \\
Epidermophyton & - & - & - \\
\hline
\end{tabular}

鞘, 毛小皮および毛皮質内に PAP 陽性の菌要素 が認められた (Fig. 5, Fig. 6).なお，このポリ クローナル抗体による PAP 法（1,000×希釈）で は, Trichophyton sp., Microsporum sp., Epidermophyton sp. はいずれも染色されなかった (Table 1).また, この両抗体とも $1,000 \times$ 希釈で は，対照としたTrichophyton glabrumによる頭 部白癖のホルマリン・パラフィン切片内の毛内菌 要素も, PAP 法陰性であった（Table 2).

Table 2. Difference of PAP stain between candidiasis and tinea capitis

\begin{tabular}{lrccc}
\hline & & This case & Candida granuloma & Tinea capitis \\
\hline Anti-Candida monoclonal antibody & $100 \times$ & + & + & + \\
Anti-Candida monoclonal antibody & $1000 \times$ & + & + & - \\
Anti-Candida polyclonal antibody & $1000 \times$ & + & + & - \\
\hline
\end{tabular}

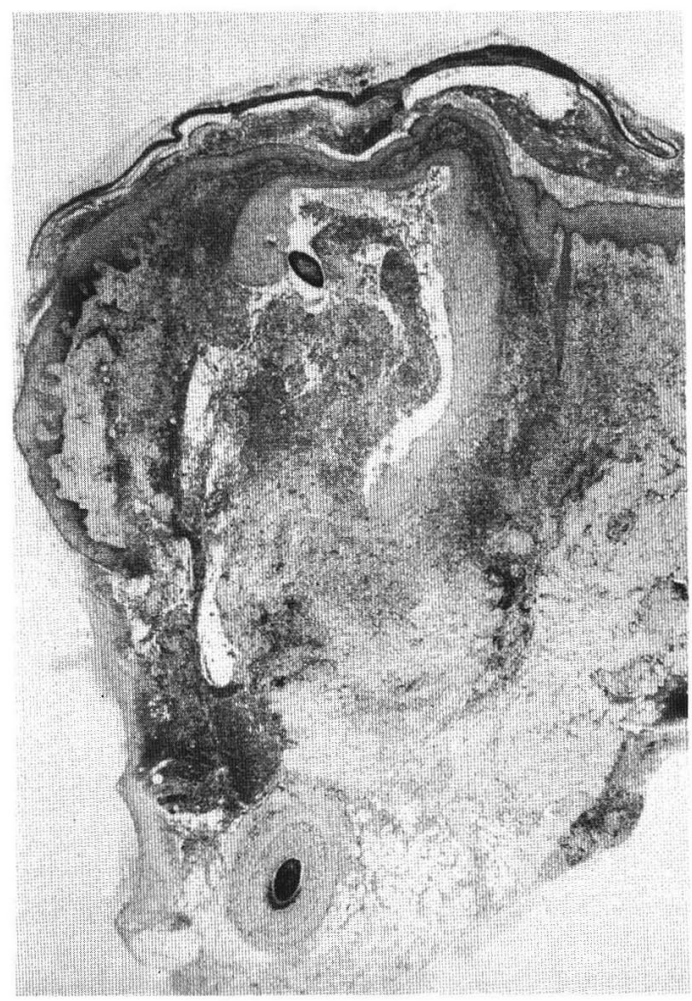

Fig. 3. Biopsy specimen revealing dense PMN infiltration and hair follicle destruction. (HE stain)

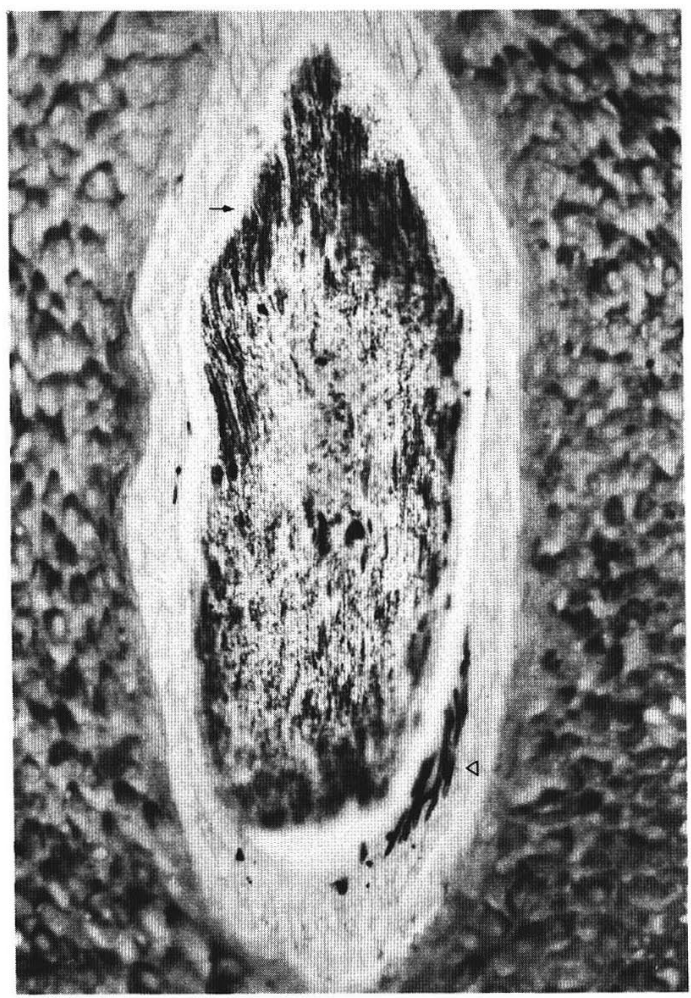

Fig. 4. Fungus elements in internal root sheath $(\triangleleft)$ and hair cortex $(\rightarrow)$. (PAS stain) 


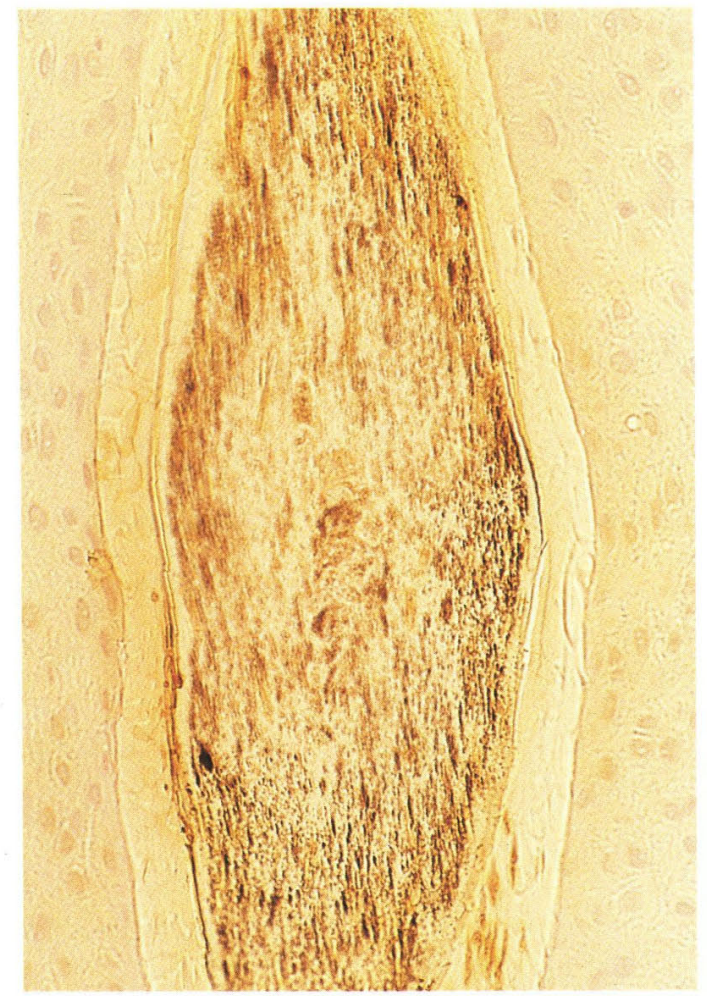

Fig. 5. Candida elements in internal root sheath and hair cortex, oblique section. (PAP stain)

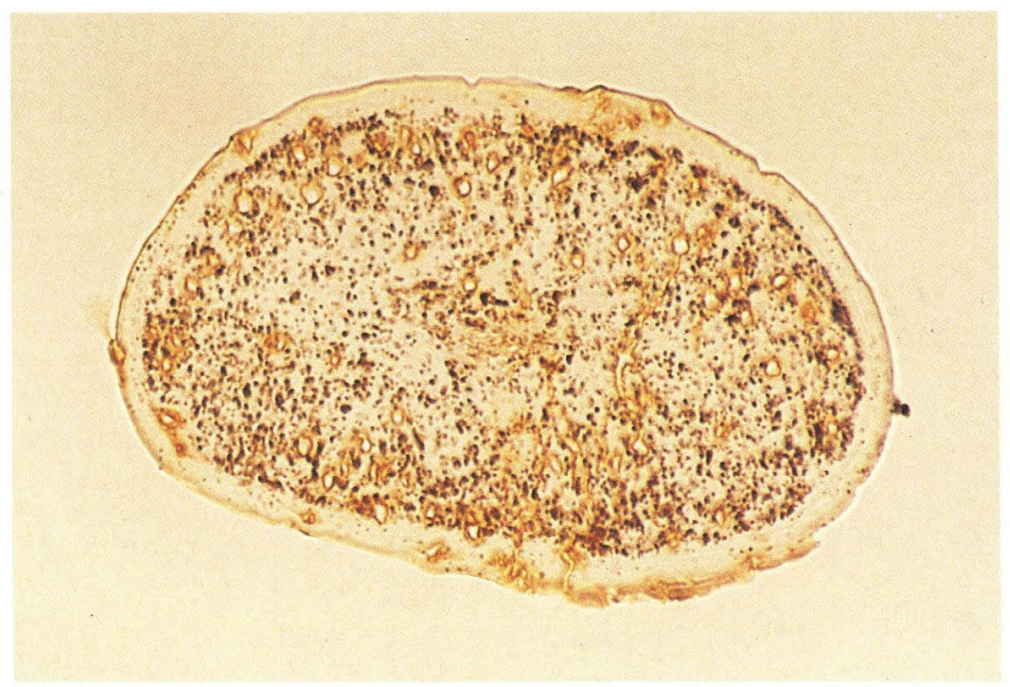

Fig. 6. Candida elements in hair cuticle and hair cortex, horizontal section. (PAP stain) 
Table 3. Proteinase activities produced by Candida albicans (by T. Yoshiike)

\begin{tabular}{lccc}
\hline \multirow{2}{*}{ medium } & cell count $/ \mathrm{m} l$ & \multicolumn{2}{c}{ enzyme activity $\mathrm{OD}_{280}$} \\
\cline { 3 - 4 } & & \multicolumn{2}{c}{ substrate } \\
\cline { 3 - 4 } hair & $7.5 \times 10^{7}$ & 0.06 & 0.05 \\
& $6.0 \times 10^{7}$ & 0.07 & 0.00 \\
\multirow{2}{*}{ corneum } & $2.5 \times 10^{8}$ & 0.10 & 0.01 \\
& $2.4 \times 10^{8}$ & 0.13 & 0.02 \\
\hline
\end{tabular}

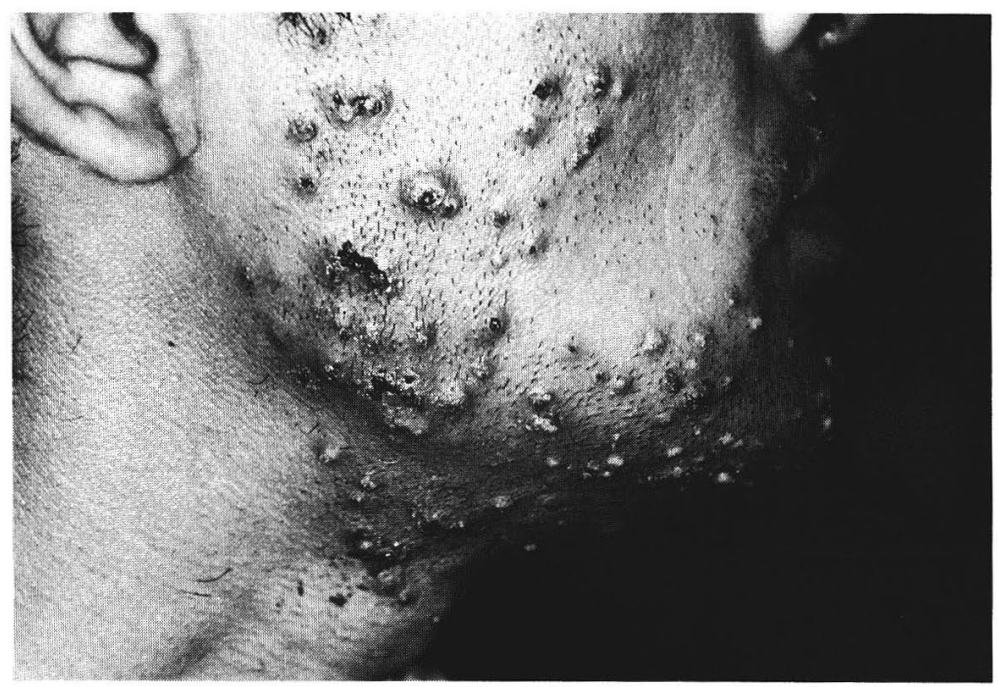

Fig. 7. Pustules and crusts on beards and whiskers after medication with griseofulvin.

分離菌によるタンパク分解酵素活性：本患者か ら分離された Candida albicansのタンパク分解 酵素 (Candida albicans producing proteinase, CAPP）活性がヒト皮膚角質抢よびヒト毛髪を基 質として, Hattori ら4) の方法に従って順天堂大 学医学部皮虐科学教室で測定された（Table 3). これによると，栄養源が毛髪・角質を問わず，角 質溶解性 proteinase に比べて, 毛溶解性 proteinase はほとんど誘導されなかった。

治療および経過 : クロトリマゾールクリームを 約 2 週間外用したが，改善はほとんど認められな かった. 次いで, 微粒子グリセオフルビン 1 日 375 $\mathrm{mg}$ を 1 週間内服したところ，膿疮は拡大し，排 膿・痂皮・血痂も見られるようになり，皮疹は明 らかに悪化した (Fig. 7). 次いで, フルシトシン
1 日 $4.5 \mathrm{~g}$ を 5 日間内服したが, 膿疮が多少小型化 した程度で効果はほとんど見られなかった。この 時点で支膚生検が行われた。そして，9月3 日よ クイトラコナゾール 1 日 $100 \mathrm{mg}$ の内服を開始し たところ，1週間後には膿疮は縮小・乾燥化し， 4 週間後には膿疮はほとんど消失し, 著明に改善 した（Fig. 8).しかし,この時点でも, 須毛の $\mathrm{KOH}$ 法で真菌性菌要素が認められたため, イト ラコナゾールを引き続き投薬したが，患者はこの 1 週間後に覚醒剂使用のため逮捕され, 以後詳細 は不明である。

\section{考察}

本症例は, 皮疹が須毛を中心とした膿疮である こと, 膿疮中心部の毛に $\mathrm{KOH}$ 法で毎回胞子と仮 


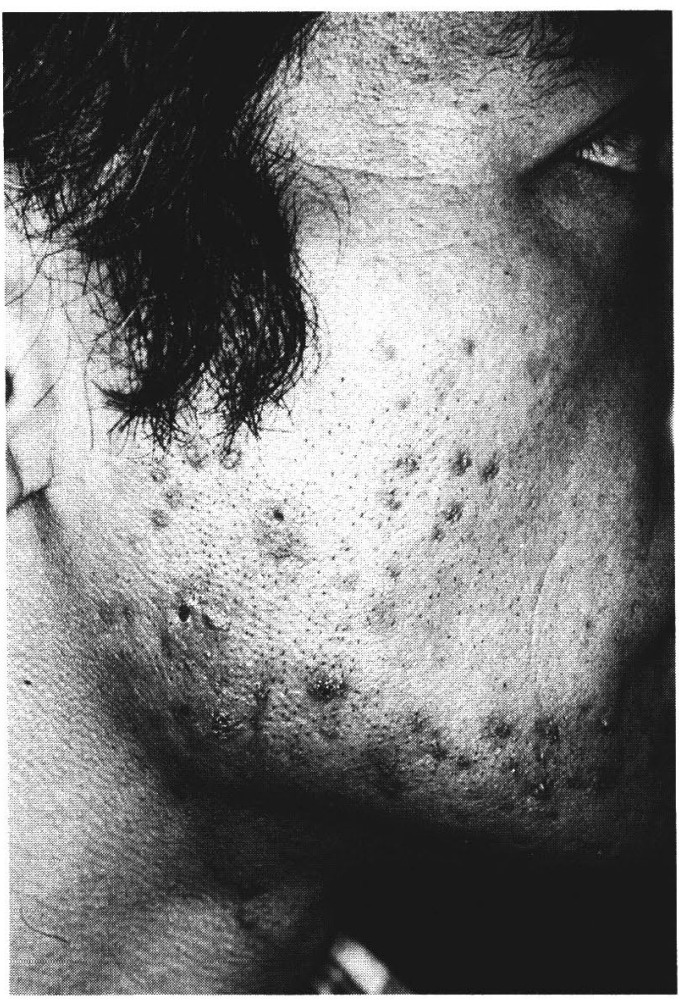

Fig. 8. Pustules and papules decreased in size and number after itraconazole medication.

性菌糸が認められたこと, 数回にわたる毛の真菌 培養でCandida albicans のみが発育したこと， 病理組織学的に急性の毛包炎で内毛根鞘および一 部毛内に仮性菌系を思わせる菌要素が認められた こと, グリセオフルビン内服で悪化，イトラコナ ゾール内服で改善が認められたことなどより，力 ンジダ性毛瘡との診断で間違いないものと思われ る.

自験例で特筆すべきことは, 毛内にカンジダと 思われる菌要素が侵入していたことである。カン ジダは毛を侵すことがないというのがこれまでの 常識で1), 毛内の菌要素は抗カンジダ・モノクロー ナル抗体 (DAKO 社, 1,000×) を用いたPAP 法 で陽性であっても白癬菌の可能性は否定できない との疑問が多く出された5). 諸外国の文献による と, カンジダの毛内増殖のみられたカンジダ性毛 瘡の 1 例2)やへロイン常習者にみられたカンジダ 性毛包炎の 5 例3) などの報告がある。この後者の
Rodriguez らの報告では，5例中 4 例で毛内にカ ンジダの菌要素が認められたと述べているが，こ れらの症例は，いずれも培養および病理組織学的 所見によるもので, 毛内の菌要素が免疫組織化学 的にカンジダであることを証明したものではない． 自験例は, 当初抗カンジダ・モノクローナル抗体 (DAKO 社，1,000×）を用いたPAP 法で毛内の 菌がカンジダであることを証明したが，更に確認 するために，抗カンジダ・ポリクローナル抗体 (北里大学病理学教室製, $1,000 \times$ ) を用いた PAP 法でも検討した。結果は同一で, 内毛根鞘の菌要 素も毛内の菌要素もカンジダであることが確認さ れた。

そこで, Candida albicans は毛を分解するタン パク分解酵素を有しているか否かということが問 題となった. Candida albicans が角質溶解性タン パク分解酵素 (CAPP) を産生することは既に報 告されている6)が, 毛を溶解する CAPPは未だ誘 導されていない4). 自験株についても, 順天堂大 学医学部皮䖉科学教室, 小川秀興教授, 吉池高志 先生の御好意で検討されたが, 結果は同じく, 毛 溶解性 proteinase はほとんど誘導されなかった。 この結果は, 自験株も他の Candida albicans と 同様に，毛に侵入し難い菌であることを示してい る。しかし, 毛に侵入し得る可能性を全面的に否 定するものではないと考える.

自験例は覚醒剂中毒患者であるが, 胃部分切除 後, 高カロリー経静脈栄養と多量の抗生剂投与を 受けている間に発症しているので, これらを誘因 と考えるのが常識的と思われる。しかし, 先にも 述べたごとく麻薬中毒患者に生じたカンジダ性毛 包炎の報告があり，また覚醒剤中毒患者にカンジ ダ性髄膜炎が発生したとの報告7) もあり，カンジ 多性毛瘡ないしカンジダの毛内侵入の誘因の一つ として麻薬执よび覚醒剤中毒を考慮して扔く必要 があるように思われる。

カンジダ性毛瘡は, 今後毛内の菌要素について 再検討されるべきであるが, 特に麻薬中毒ないし 覚醒剤中毒患者においては念を入れて検討する必 要があるように思われる。

本論文の要旨は第 33 回日本医真菌学会 $(1989$ 年 9 月，沖縄市）において報告した。なお，抗力 ンジダ家兔抗血清を提供して頂いた北里大学医学 部病理学教室の久米光先生と proteinase 誘導の実 
験をして頂いた順天堂大学医学部皮膚科学教室の 吉池高志先生に深謝致します.

\section{文献}

1）笠井達也, 三浦幹枝 : カンジダ性毛瘡. 臨皮 31 : 281-286, 1977.

2) Lindemayr $\mathrm{H}$ und Thurner $\mathrm{J}$ : Folliculitis barbae candidomycetica durch Candida parapsilosis. Hautartz 30 : 597-599, 1979.

3) Rodriguez PC, Lopez FV, Caballero LR and Yus ES: Foliculitis candidiásica en heroin ómanos. Estudio histol ógico. Med Cut ILA 15 : 411-417, 1987.
4) Hattori M, Yoshiura $K$, Negi $M$ and Ogawa $\mathrm{H}$ : Keratinolytic proteinase produced by Candida albicans. Sabouraudia 22:175 $-183,1984$.

5）内藤静夫, 高橋泰英, 中嶋 弘: カンジダ性毛瘡 の 1 例. 第 33 回日本医真菌学会, 沖縄, $1989,9$.

6）松田和子, 服部道廣, 鈴木佳子, 佐藤壮彦, 小川 秀興：C. albicans の産生する角質溶解性蛋白分 解䤃素の 2,3 の生化学的性状について. 日皮会 誌 $93:$ 463-466, 1983.

7) Kantor HL, Emsellem HA, Hogg JE and Simon GL : Candida albicans Meningitis in a Parenteral Drug Abuser. South Med J 77 : 404-405, 1984.

\title{
Folliculitis barbae candidomycetica with endothrix Candida-growth verified by PAP method
}

\author{
Shizuo Naito, Yasuhide Takahashi* and Hiroshi Nakajima* \\ Division of Dermatology, Ushioda General Hospital, Yokohama, Japan \\ * Department of Dermatology, Yokohama City University School of Medicine, \\ Yokohama 232, Japan
}

A 43-year-old man with folliculitis barbae candidomycetica who is a methamphetamine abuser is reported. After an operation of gastric perforation and the administration of several antibiotics, many pustules emerged primarily in his bearded and whiskered area. $\mathrm{KOH}$-mount examination revealed many fungal elements in the extracted beards, and histopathological study revealed dense PMN infiltration and abscess formation around a destroyed hair follicle. PAS stain showed many fungal elements of spores and pseudohyphae in inner root sheath and hair cortex. In addition, endothrix Candida-growth was verified by PAP method using monoclonal and polyclonal antiCandida antibodies. Candida albicans type A was isolated and identified from the beard. Clotrimazole application and griseofulvin medication were both ineffective, but the skin lesions were finally successfully treated with itraconazole medication. 